\section{ANALYSIS OF FORCES INDUCED BY COATED CUTTING TOOLS AT WET AND DRY GROOVING OF HARDENED STEEL}

\author{
MIROSLAV PISKA, PETRA SLIWKOVA \\ ${ }^{1}$ Brno University of Technology, Faculty of Mechanical \\ Engineering, Institute of Manufacturing Technology, Brno, \\ Czech Republic \\ DOI: 10.17973/MMSJ.2020_03_2019125 \\ e-mail: piska@fme.vutrbr.cz
}

ABSTRACT

The paper deals with a CNC grooving of hardened low-alloyed steel in flood and dry cutting conditions. A new generation of nanocomposite PVD coatings (Ti,Al)N and $\left(\mathrm{Ti}_{0.4}, \mathrm{Al}_{0.6}\right) \mathrm{N}$ deposited on WC-Co carbide when cutting at high cutting speed was characterized and compared. The statistical analysis of force time series acting during the machining, wear and tool life of the cutting tools have been assessed. Grooving with the coated tools and flood cooling showed to be successful and the quality of machined surface was high. The dry machining conditions were proven as disadvantageous and not recommended for any industrial practise, because the life time of the cutting tools was more than $85 \%$ shorter compared to the grooving with flood cooling.

KEYWORDS

Grooving, PVD coatings, (Ti,Al)N, (Ti $\left.i_{0.4}, A l_{0.6}\right) \mathrm{N}$, cutting forces, dry machining, hardened steel.

\section{INTRODUCTION}

Growing requirements for a high precision machining set high demands for quality of cutting tool material. This is especially true for grooving operations - Figure 1, where width and position of a groove must be strictly precise [Fofana 2003, Jawahir 2000, Ee 2003]. To solve that problem it is necessary to consider many factors - workpiece material, cutting tool geometry, cutting conditions, wear and a use of cooling fluid. The main factor today which benefits to the life time of cutting tools is deposition of hard and wear resistant coatings [Humar 2008, Derflinger 2006, Klostermann 2005, Rech 2006, Bobzin 2017, Vijayan 2018].

In this work the new nanocomposite coatings (Ti,Al)N and $\left(\mathrm{Ti}_{0,4}, \mathrm{Al}_{0,6}\right) \mathrm{N}$ were tested to assess a quality of grooves in conditions of dry and wet machining of hardened steel.

\section{THEORY OF THE CUTTING TEST}

Forces acting during the machining - Figure $1 \mathrm{~b}$ - provide valuable information about machining accuracy, machined surface quality, machine tool vibration, power requirements, wear and tool life [Parakkal 2001, Wanigarathne 2005]. Theoretically, resultant force $F$ in turning operation, which includes cutting force $F_{c}$, feed force $F_{f}$ and passive force $F_{p}$, could be defined from empirical expressions (1-4) [Shaw 2005, Forejt 2006]:
$F_{c}=C_{F c} \times a_{p}^{x_{F i}} f_{p}^{y_{F i}}$

$F_{f}=C_{F f} \cdot a_{p}^{x_{F f}} f_{p}^{y_{F f}}$

$F_{p}=C_{F p} \cdot a_{p}^{x_{F p}} f_{p}^{y_{F p}}$

$F=\sqrt{F_{e}^{2}+F_{f}^{2}+F_{p}^{2}}$,

where $C_{F c}, C_{F f}, C_{F p}$ are material constants and $x_{F c} x_{F f} x_{F p}$ express the influence of axial depth of the cut and $a_{p}$, and $y_{F c}, y_{F f}, y_{F p}$ the effect of the feed on the tool force loading.
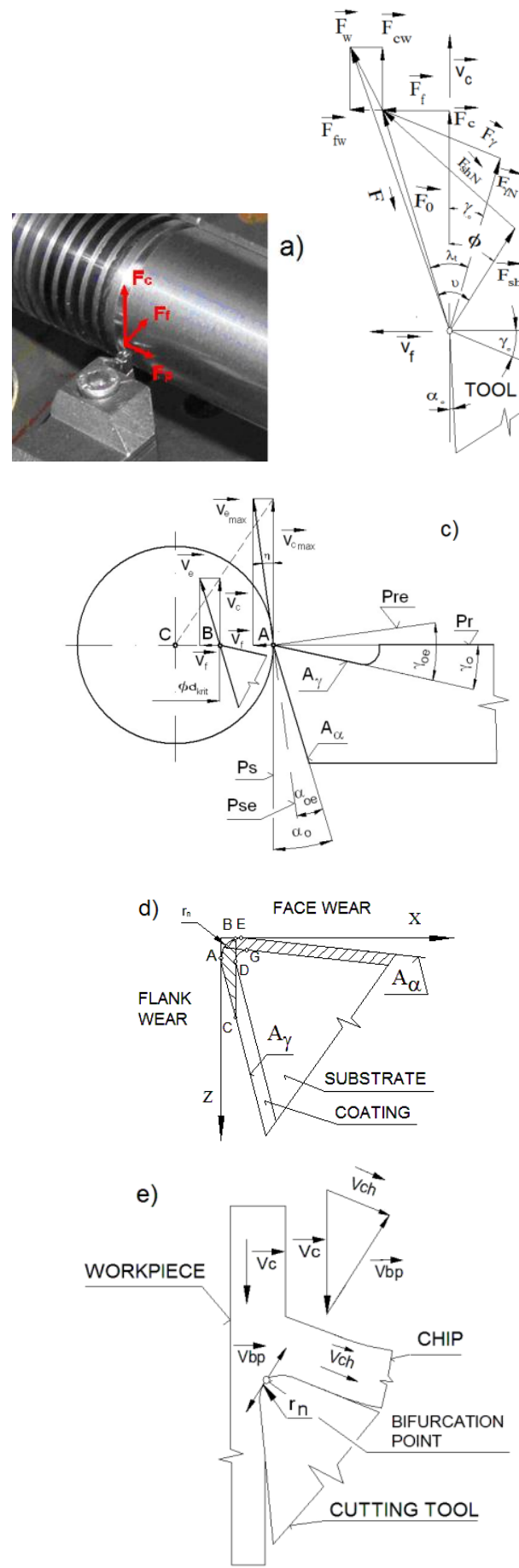

Figure 1. Grooving and cutting-off analysis. (a) An example of the tool: $F_{c}$ - cutting force, $F_{f}$ - feed force, $F_{v N}-$ force acting perpendicularly the rake plane $A_{\gamma}, F_{\chi}$ - force acting along the rake $A_{\gamma}, F_{s h N}$ - force acting perpendicularly to the shear plane, $F_{s h}$ - force acting along the rake shear plane, $F_{0}$ - resultant force (without wear of tool), $F$ - total force (regarding wear of tool), $\phi$ - shear angle, $\lambda_{t}$ - Coulombian angle of friction, $P_{r}-$ tool reference plane, $P_{r e}-$ working cutting edge plane, $P_{s}-$ 
tool cutting edge plane, $P_{s e}-$ working cutting edge plane, (b) loading of the tool and force composition regarding also wear of cutting tool, (c) the change of effective tool geometry: $\gamma_{o}-$ tool orthogonal rake angle, $\gamma_{o}$ - working tool orthogonal rake angle, $\alpha_{o}$ - tool orthogonal rake angle, $\alpha_{o e}$-working tool orthogonal rake angle, (d) flank and face wear of the coated tool: $A_{\alpha}$ - flank face, (e) speed vector diagram for chip production $\left(v_{c}\right.$ - cutting speed, $v_{c e}$ - effective cutting speed, $v_{f}$ - feed velocity, $v_{c h}$ - chip velocity, $v_{b p}$ - velocity at the bifurcation point, $r_{n}$ cutting edge radius).

However, these formulations do not include the effect of wear as a function of cutting time, so it should be modified into the equations (5-8):

$$
\begin{aligned}
& F_{c}=F_{c 0}+F_{C W} \\
& F_{c o}=A_{D}, k_{c}=a_{0} \\
& F_{C W}=a_{1} t+a_{2} t^{2} \\
& F_{c}=a_{0}+a_{1} t+a_{2} t^{2}
\end{aligned}
$$

Where $F_{c o}$ represents the cutting force for a sharp cutting edge and $F_{c w}$ includes the effect of wear on the cutting force. According to our experimental work, polynomial functions reflect the wear phenomena very relevantly for all measured components in the cutting time as a common function. The other components can be simplified in the following forms (910).

$$
\begin{aligned}
& F_{f}=k_{F f}(t) \cdot F_{e} \\
& F_{p}=k_{F p}(t) \cdot F_{e}
\end{aligned}
$$

The magnitude of the resultant force was the same for the both theoretical variations.

A typical problem linked to the grooving is the change of cutting speed according to the cut diameter when machining with the constant number of rotation - Figure 1c. The effective geometry of tool changes and a critical diameter when effective flank angle is zero can be predictive. In that moment cutting tool can be overloaded and broken.

A special attention should be paid to the coated tools where wear developments passes through the coatings and when the substrate is revealed. The mechanics of the wear is affected by the changes in momenta and inertia at the interface when chip is produced - Figure 1e.

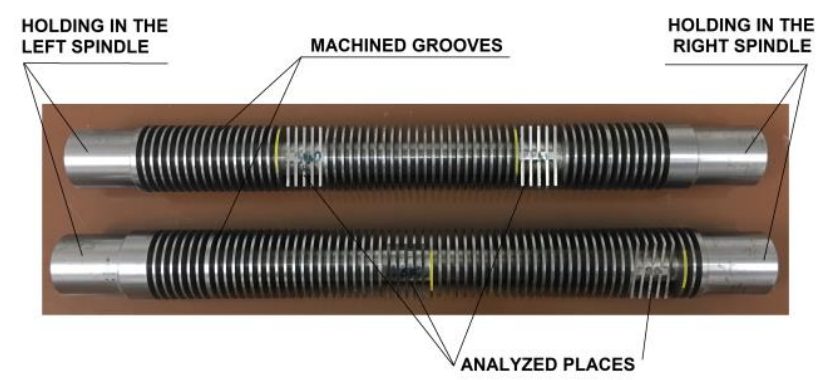

Figure 2. Examples of the workpieces and analyzed places.

\section{EXPERIMENTAL PROCEDURE}

The material of a workpiece was hot rolled steel DIN $50 \mathrm{CrV} 4$ with tensile strength $\mathrm{Rm} 885-1,030 \mathrm{MPa}$, hardened to $30 \pm 1$ HRC. In total, 45 bars have been tested, each $\varnothing 38 / 380 \mathrm{~mm}-$ Figure 2. The width of a groove was $3 \pm 0.05 \mathrm{~mm}$, depth of grooves $9.5 \mathrm{~mm}$, pitch of grooves $4.5 \mathrm{~mm}$. Chemical composition of the material is listed in Table 1. Structure of the material was created by tempered martensite, carbides and fine dispersion of secondary carbides, residual austenite, oxides and MnS inclusions - Figure 3. Machining of a workpiece was carried out in wet and dry cooling conditions as short time cutting tests. The Kistler ${ }^{\circledR}$ 9257B dynamometer and charge amplifiers Kistler ${ }^{\circledR}$ 9011A, fully controlled by PC, were used for cutting force measurements, fixed to the lathe SU50 2A.

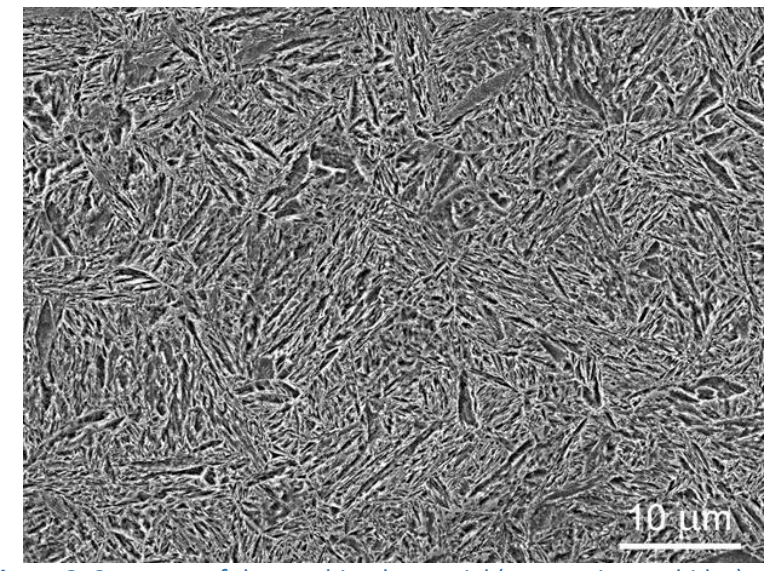

Figure 3. Structure of the machined material (martensite, carbides). Nital $2 \%$.

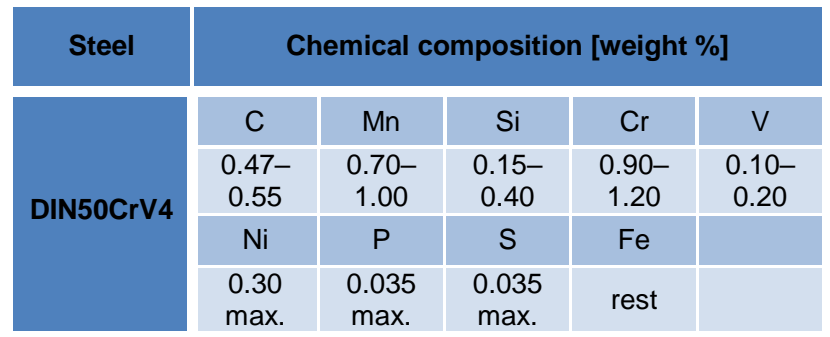

Table 1. Workpiece material (Mn-Cr-V hardened steel)

Cutting inserts LCMF 031602-F; grade HF10 (Dormer Pramet ${ }^{\circledR}$ ) Figure 4 - were used for the grooving, clamped to the tool holder ISO GFIR/L 1616 H 03 - Figure 3b. The cemented carbide was made from $W C+C o(90 \% W)$, grain size $2-4 \mu \mathrm{m}$. The geometry of the cutting inserts is shown in the Figure $4 a, c$ where the parameters are: $a=3 \pm 0.05 \mathrm{~mm}, \mathrm{l}=16.4 \mathrm{~mm}, r_{\varepsilon}=0.2$ $\mathrm{mm}$. Roughness of the rake face measured along and perpendicularly to the main cutting edge in terms of Ra (arithmetic average of the roughness profile), Rq (root mean square deviation) and $\mathrm{Rz}$ (average maximum height of assessed profile) was very good - see Figure $4 \mathrm{c}$, as well as the cutting edge radius (about $30 \mu \mathrm{m}$ ).

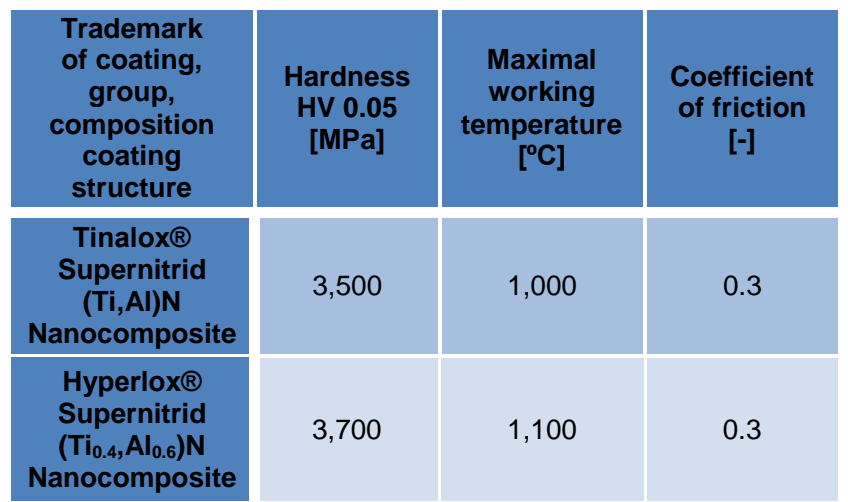

Table 2. Nominal physical properties of the tested PVD coatings 

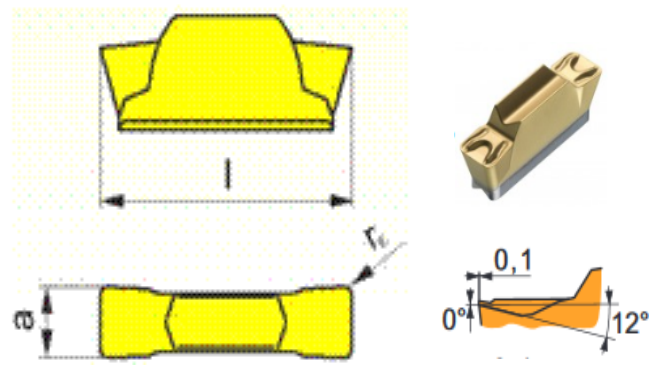

a)

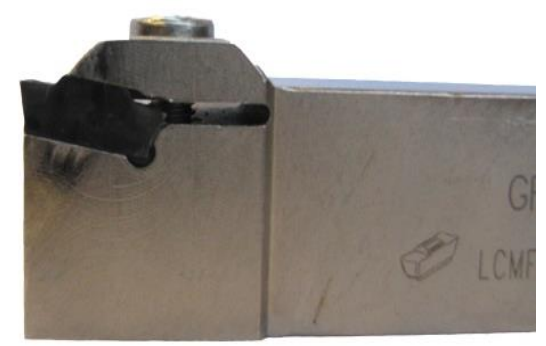

b)

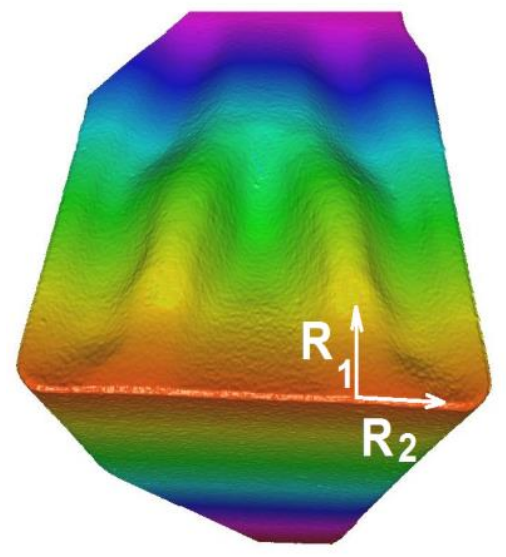

$$
\mathbf{R}_{1}: \begin{aligned}
& \text { Ra: } 0.754 \mu \mathrm{m} \\
& \text { Rq: } 0.930 \mu \mathrm{m} \\
& \text { Rz: } 3.881 \mu \mathrm{m}
\end{aligned} \quad \mathbf{R}_{2}: \begin{aligned}
& \text { Ra: } 1.034 \mu \mathrm{m} \\
& \text { Rq: } 1.441 \mu \mathrm{m} \\
& \text { Rz: } 6.790 \mu \mathrm{m}
\end{aligned}
$$

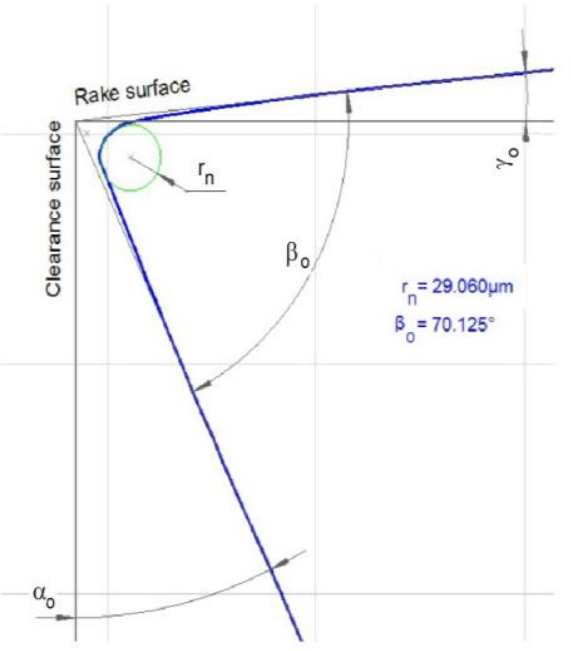

c)

Figure 4. Cutting tool: a) the insert geometry; b) the tool holder; c) the microgeometry of the edge
New nanocomposite PVD coatings $(\mathrm{Ti}, \mathrm{Al}) \mathrm{N}$ and $\left(\mathrm{Ti}_{0,4}, \mathrm{Al}_{0,6}\right) \mathrm{N}$ Table 2 - were deposited on the substrates by means of a magnetron sputtering technology by $\mathrm{CemeCon}^{\circledR}$ with CC800/9ML system use. The temperature of inserts during the coating deposition process was between $450 \div 480^{\circ} \mathrm{C}$, thickness of the deposited coatings was $6 \pm 1 \mu \mathrm{m}$ (proved by the ballerosion Kalo-test, see Figure 5). In general, these coatings remain normally stable in the single-phase cubic structure used for metal working applications up to more than $800^{\circ} \mathrm{C}$ [Bobzin 2017, Vijayan 2018].

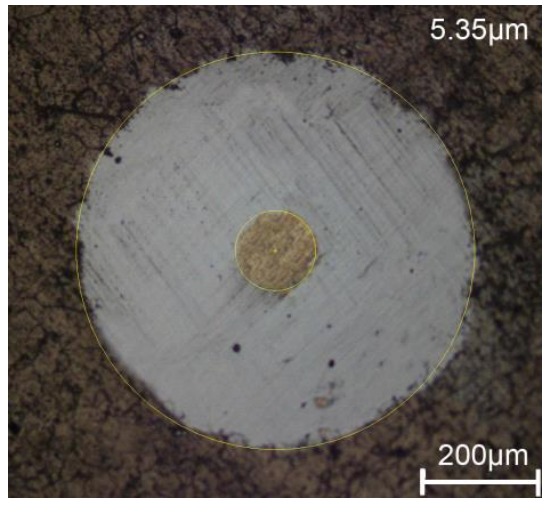

a)

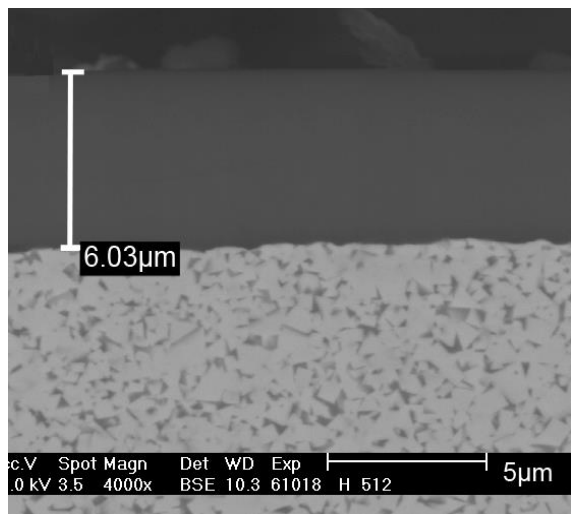

b)

Figure 5. Analyses of the coatings: a) Kalo-test of (Ti,Al)N coating; b) $\left(\mathrm{Ti}_{0.4}, \mathrm{Al}_{0.6}\right) \mathrm{N}$ coating structure (BSE)

Morphologies of the coatings surfaces were studied with the use of scanning electron microscope microscope $\mathrm{XL} 30$ Philips $^{\circledR}$ working in SE and BSE regimes. The PVD coatings (Ti,Al)N and $\left(\mathrm{Ti}_{0.4}, \mathrm{Al}_{0.6}\right) \mathrm{N}$ had a very fine, pore free structure and uniform interface, which was beneficial to adhesion - Figure 5 . Both types of coatings had an increased hardness compared to standard (Ti,Al) N coatings as well as superior stability. It was due to their nanocomposite structure where crystals of $(\mathrm{Al}, \mathrm{Ti}) \mathrm{N}$ (enriched with Al) were embedded into matrix $(\mathrm{Ti}, \mathrm{Al}) \mathrm{N}$ (enriched with Ti). The cutting tests were performed on the CNC lathe Kovosvit MAS ${ }^{\circledR}$ SP 280 SY with Sinumerik 840D CNC. The workpieces were clamped with the main spindle chuck and a counter spindle chuck, so a very rigid and stabilized blank holding was realized. For the wet machining a cooling fluid ECOCOOL 68 CF2, Fuchs Oil Corporation ${ }^{\circledR}$, was applied. Cooling fluid volume concentration in water was $5-6 \%$, pressure 60 bars, fluid flow was about 0.2-0.3 liter per second. The cutting conditions and some results of the cutting tests can be seen in Figure 5. The statistical assessment was done in Minitab $^{\circledR} 18$, Pennsylvania, USA. 


\section{RESULTS}

Wear of the tested inserts had a gradual degradation behavior, with different intensiveness for the wet and dry cutting - Figure 6. During the dry grooving operation a high noise, sparkles, bad chip formation, high energy consumption, etc. were observed. Moreover, values of the cutting forces have grown considerably in comparison to wet machining, due to rake and flank wear of inserts. Values of forces acting during the wet machining are shown in Table 3 and Figure 7. The results for passive forces Fp were affected by slight chattering of the workpiece and a significantly lower rigidity of the slim tool holder in the axial direction compared to the tangential orientation. Nevertheless, all coefficients for the tool loading analyses are given in the Table 4 and Figure 8. According to the statistic assessment, the medians of total cutting forces for worn inserts with PVD $(\mathrm{Ti}, \mathrm{Al}) \mathrm{N}$ and $\left(\mathrm{Ti}_{0,4}, \mathrm{Al}_{0,6}\right) \mathrm{N}$ coatings were not equal, $(p=0.05)$ - Figure 9.

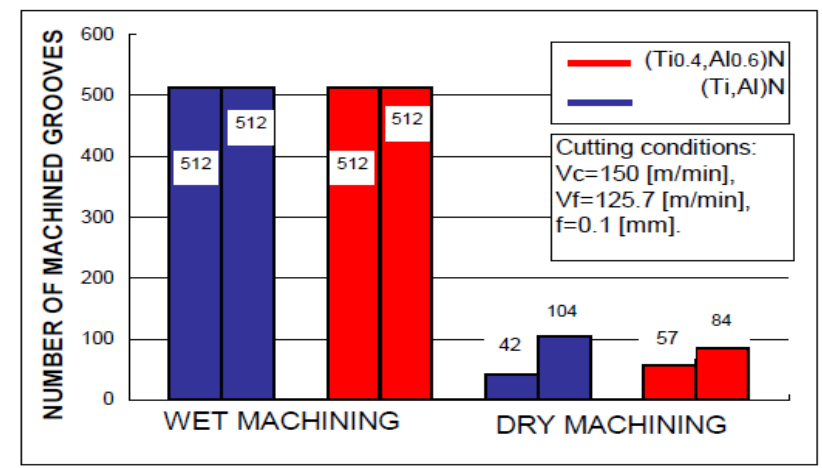

Figure 6. Cutting performance of the coated tools

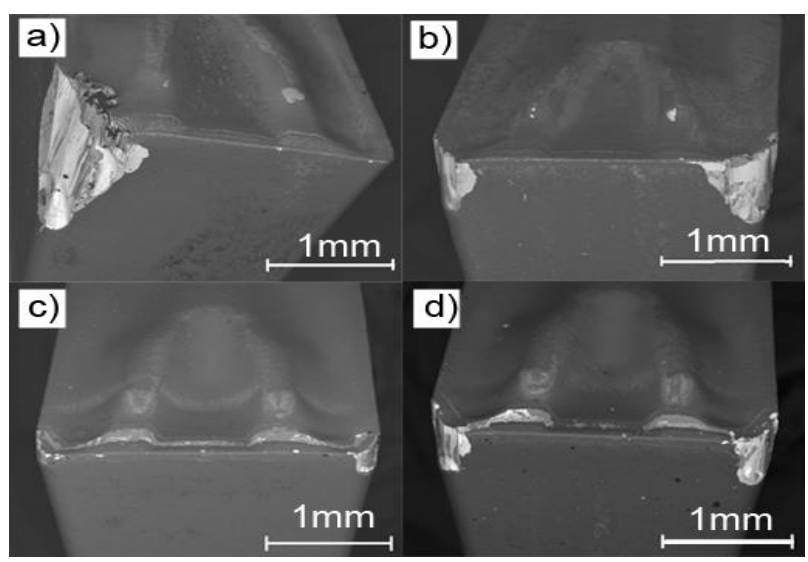

Figure 7. Abrasive wear of the cutting inserts in dry conditions a) $(\mathrm{Ti}, \mathrm{Al}) \mathrm{N}, \mathrm{b})\left(\mathrm{Ti}_{0,4}, \mathrm{Al}_{0,6}\right) \mathrm{N}$, and wet conditions - c) $\left.(\mathrm{Ti}, \mathrm{Al}) \mathrm{N}, \mathrm{d}\right)\left(\mathrm{Ti}_{0,4}, \mathrm{Al}_{0,6}\right) \mathrm{N}$

\begin{tabular}{|c|c|c|c|}
\hline \multirow{3}{*}{ Force } & \multicolumn{3}{|c|}{$\left(\mathrm{Ti}_{0.4}, \mathrm{Al}_{0.6}\right) \mathrm{N}$ Hyperlox${ }^{\circledR}$} \\
\hline & \multicolumn{3}{|c|}{ Machining time $\mathrm{t}$ [min] } \\
\hline & 0.08 & 18.99 & 42.66 \\
\hline Fc $[N]$ & $\begin{array}{c}874.88 \\
\pm 116.34\end{array}$ & $\begin{array}{c}934.43 \\
\pm 116.34\end{array}$ & $\begin{array}{r}874.88 \\
\pm 116.34\end{array}$ \\
\hline $\mathrm{Ff}[\mathrm{N}]$ & $\begin{array}{l}394.17 \\
\pm 97.99\end{array}$ & $\begin{array}{l}485.40 \\
\pm 97.99\end{array}$ & $\begin{array}{l}394.17 \\
\pm 97.99\end{array}$ \\
\hline $\mathrm{Fp}[\mathrm{N}]$ & $\begin{array}{c}1.93 \\
\pm 46.21\end{array}$ & $\begin{array}{c}5.44 \\
\pm 46.21\end{array}$ & $\begin{array}{c}1.93 \\
\pm 46.21\end{array}$ \\
\hline \multirow{3}{*}{ Force } & \multicolumn{3}{|c|}{$(\mathrm{Ti}, \mathrm{Al}) \mathrm{N}$ Tinalox$\circledast$} \\
\hline & \multicolumn{3}{|c|}{ Machining time $t$ [min] } \\
\hline & 0.08 & 18.99 & 42.66 \\
\hline $\mathrm{Fc}[\mathrm{N}]$ & $\begin{array}{c}895.24 \\
\pm 125.38\end{array}$ & $\begin{array}{r}954.95 \\
\pm 125.38\end{array}$ & $\begin{array}{l}1186.00 \\
\pm 125.38\end{array}$ \\
\hline $\mathrm{Ff}[\mathrm{N}]$ & $\begin{array}{l}350.57 \\
\pm 99.32\end{array}$ & $\begin{array}{l}453.31 \\
\pm 99.32\end{array}$ & $\begin{array}{l}592.94 \\
\pm 99.32\end{array}$ \\
\hline $\mathrm{Fp}[\mathrm{N}]$ & $\begin{array}{c}1.05 \\
\pm 42.12\end{array}$ & $\begin{array}{c}7.05 \\
\pm 42.12\end{array}$ & $\begin{array}{c}93.23 \\
\pm 42.12\end{array}$ \\
\hline
\end{tabular}

Table 3. An overview of the measured forces (means, standard deviations)

\begin{tabular}{|c|c|c|c|c|c|}
\hline & \multicolumn{5}{|c|}{$\left(\mathrm{Ti}_{0.4}, \mathrm{Al}_{0.6}\right) \mathrm{N}$ Hyperlox$\circledast$} \\
\hline & $F_{c}$ & $F_{f}$ & $F_{p}$ & $\mathrm{~K}_{\mathrm{Ff}}$ & $K_{\mathrm{Fp}}$ \\
\hline$a_{0}$ & 874 & 393.83 & 1.900 & 0.450 & 0,002 \\
\hline$a_{1}$ & 0.556 & 4.210 & 0.372 & 0.005 & $4.10^{-4}$ \\
\hline \multirow[t]{3}{*}{$a_{2}$} & 0.136 & 0.032 & -0.010 & $-6.10^{-5}$ & $1.10^{-5}$ \\
\hline & \multicolumn{5}{|c|}{ (Ti,Al)N Tinalox® } \\
\hline & $F_{c}$ & $F_{f}$ & $F_{p}$ & $\mathrm{~K}_{\mathrm{Ff}}$ & $\mathrm{K}_{\mathrm{Fp}}$ \\
\hline $\mathrm{Fc}[\mathrm{N}]$ & 895.22 & 350.15 & 1.143 & 0.388 & -0.001 \\
\hline $\mathrm{Ff}[\mathrm{N}]$ & 0.200 & 5.224 & -1.171 & $7.10^{-3}$ & $-7.10^{-4}$ \\
\hline $\mathrm{Fp}[\mathrm{N}]$ & 0.155 & 0.011 & 0.078 & $-1.10^{-5}$ & $6.10^{-5}$ \\
\hline
\end{tabular}

Table 4. Table of the statistical (regression) constant for all measured forces

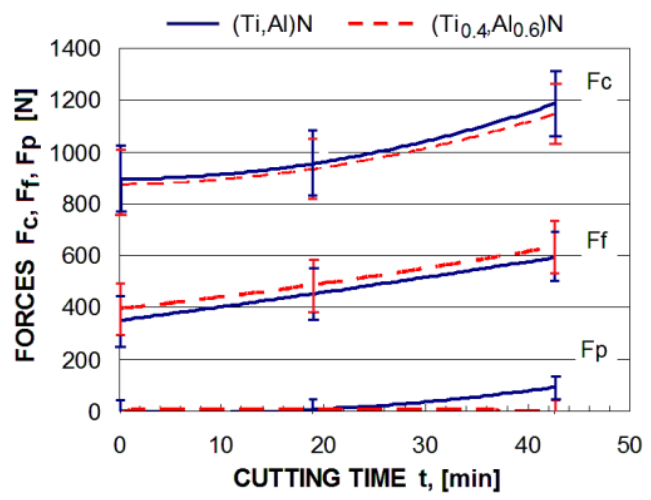

Figure 8. Time series of forces (mean values, standard deviations) 


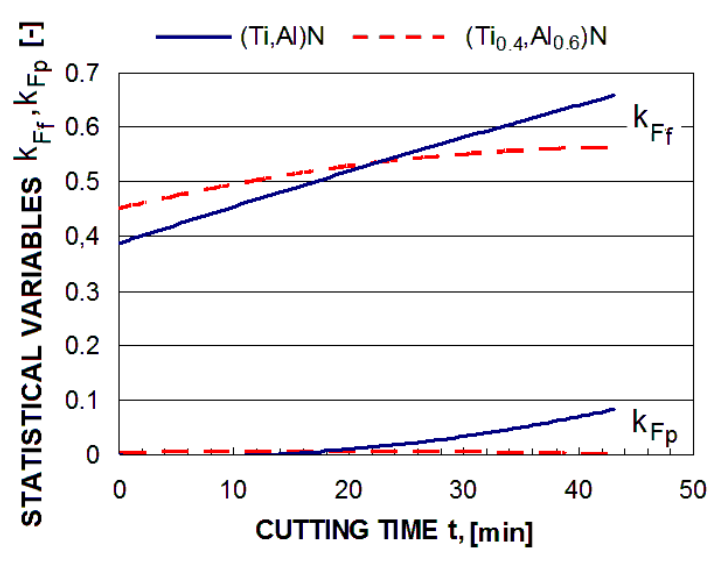

Figure 9. Time series of statistical (regression) constants

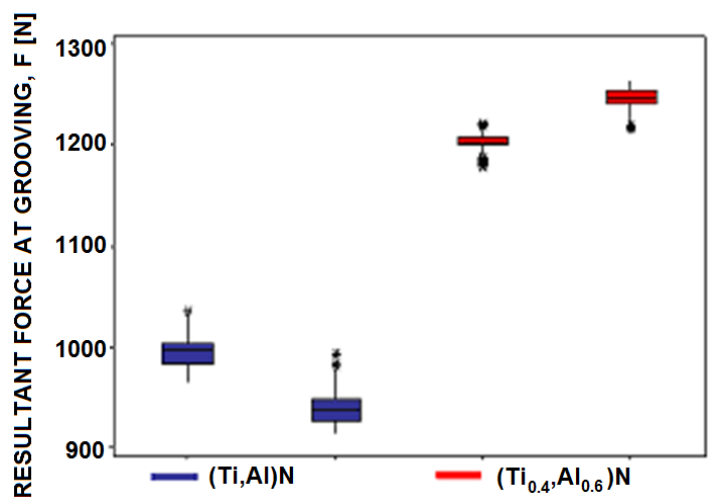

Figure 10. Comparison of the resultant forces at grooving for the tested inserts

Quality of the machined surface in terms of average roughness (Ra) was assessed with Form Talysurf Ultra 50, Taylor Hobson Precision ${ }^{\circledR}$ and Alicona IF G5 after cutting the samples. Three kinds of surfaces have been analyzed - Figure 11 - in the terms of roughness. The quality of side surfaces - left - marked as $\mathrm{Ra}(\mathrm{L})$ and right $\mathrm{Ra}(\mathrm{R})$, that were better in comparison to the front $\operatorname{Ra}(\mathrm{F})$ (by $15-20 \%$ ) - Figure 12,13. No significant difference between $\operatorname{Ra}(\mathrm{L})$ and $\operatorname{Ra}(\mathrm{R})$ was found $(p=0.05)$ for most measurements. Average roughness values were showed increasing values with a number of the machined grooves Figure 14. This process had a systematic behaviour with a normal data distribution, $(p=0.05)$.

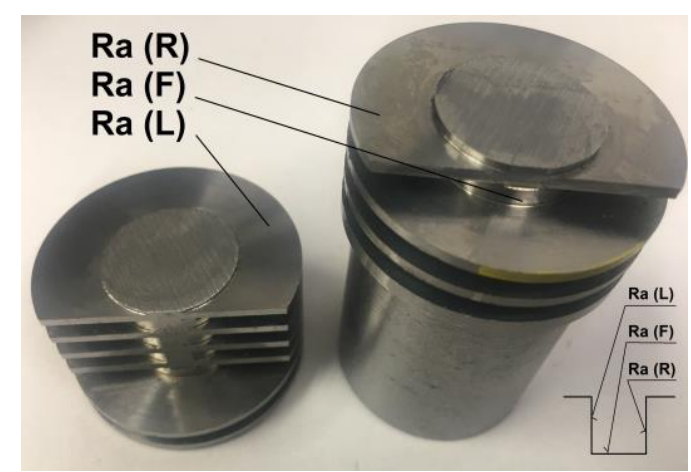

Figure 11. An example of samples for the surface analyses, positions of measurements

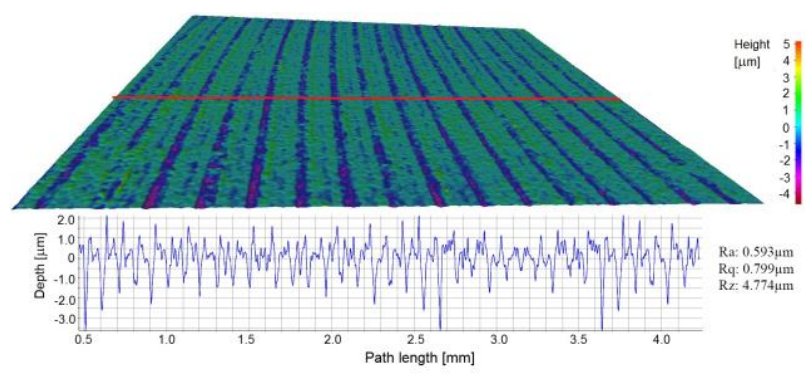

Figure 12. An example of the machined surface on the left side of the groove $\mathrm{Ra}(\mathrm{L})$

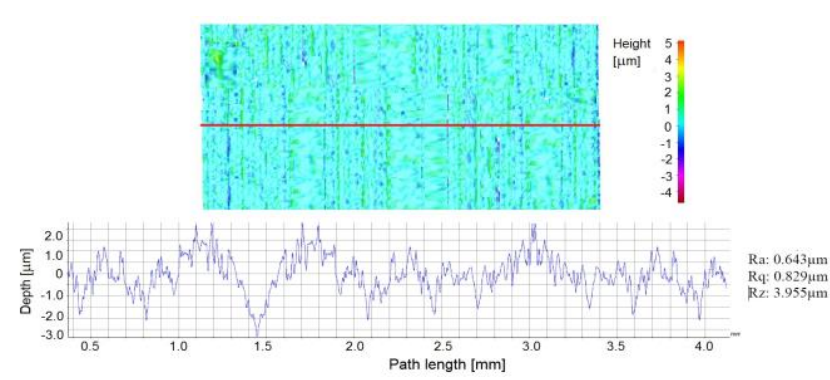

Figure 13. An example of the machined surface on the front side of the groove $\mathrm{Ra}(\mathrm{F})$

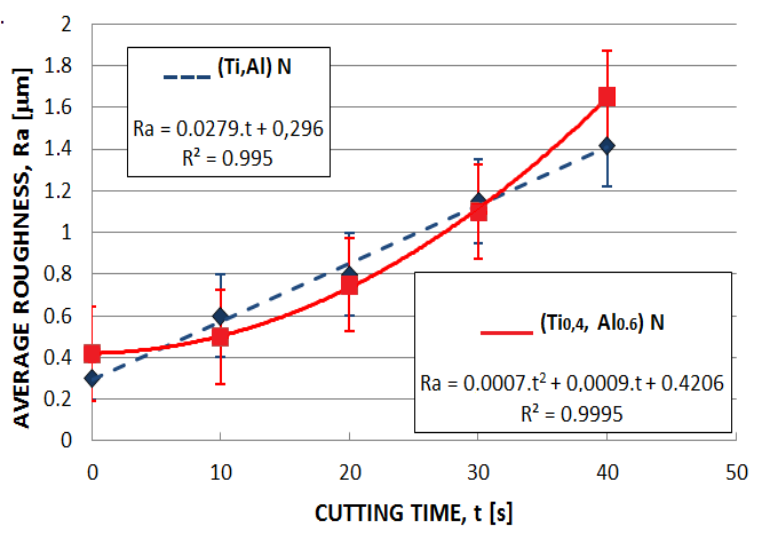

Figure 14. The average roughness of the machined side groove surfaces (the parameter $\mathrm{R}^{2}$ reflects the level of statistical correlation)

\section{DISCUSSION}

The low cutting performance of the coated tested inserts without cooling was surprising compared to our previous research works. However, if the high mechanical properties of the machined material, dry cutting conditions and the fact that the coatings work as a good thermal insulation barrier preventing the heat flux into the slim cutting tool, then a simplified calculation for the heat generation and prevailing distribution into chip can be written as:

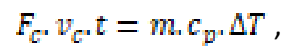

in which apart the already mentioned symbols $t$ is the time for cutting, $m$ is mass of material converted into chip, $c_{p}$ is specific heat capacity, and $\Delta T$ is the temperature rise of the chip (all other sources and ways of distributions are neglected). So the mass of produced chip via plastic deformation $m$ can be rewritten according the un-deformed chip cross section $A d$ as 
function of the feed per rotation $f$, axial width of cut $a_{e}$, specific mass density and specific cutting condition

$m=A_{D^{*}} v_{C} \rho_{x} t=f_{x} a_{e^{*}} v_{C} \rho_{x} t$

and after a simplification the expected temperature rise can be predicted as

$\Delta T=\frac{F_{e}}{f \cdot a_{i-1} p c_{p i}}$.

Taking into consideration the real cutting conditions $\left(v_{c}=150\right.$ $\mathrm{m} / \mathrm{min}, f=0.1 \mathrm{~mm}, a_{e}=3 \mathrm{~mm}$ ), mass per unit volume ( $\rho=7800$ $\left.\mathrm{kg} \cdot \mathrm{m}^{-3}\right)$, specific heat capacity $\left(c_{p}=460 \mathrm{~J} \mathrm{~kg}^{-1} \mathrm{~K}^{-1}\right)$ and measured values of $F_{c}$ (900 N approximately for the sharp cutting edge), then the temperature rise is much bigger (more than $800^{\circ} \mathrm{C}$ ) then the temperatures of the coating deposition process $\left(450 \div 480^{\circ} \mathrm{C}\right)$. However, for the referred limited working temperatures $\left(1,000^{\circ} \mathrm{C}\right)$ the needed cutting force should be about $1,000 \mathrm{~N}$. The measured values of the cutting force in the end of life reached $1,200 \mathrm{~N}$, so the flood cooling is really necessary and calculated value of the cooling intensity for the machine and cutting process more than $1 \mathrm{kw}$. The roughness parameters measured with both devices showed very similar results (due to matt machined surfaces).

\section{CONCLUSIONS}

Several conclusions from the research work can be made:

- excellent cutting performances of the PVD coated tools when grooving were proved experimentally, however, the effective flood cooling is needed;

- the life time of the cutting tools was for $85 \%$ longer compared to dry machining, and exceeded 25 minutes of machining at the cutting speed of $150 \mathrm{~m} / \mathrm{min}$ and feed per rotation $0.1 \mathrm{~mm}$ for the tempered martensitic steel;

- lower average values of the total forces were found during the wet machining - for both types of coatings the reduction was $250 \mathrm{~N}$ approximately, with lower values of their variances also (30\%);

- no continual chip formation was observed in dry machining, but rather poor material forming was observed, accompanied with formation of macro-particles, high noise, tendency to chattering and rapid tool wear or insert fracture;

- a statistically significant difference between medians of the total cutting forces for inserts with PVD (Ti,Al)N and $\left(\mathrm{Ti}_{0.4}, \mathrm{Al}_{0.6}\right) \mathrm{N}$ coatings was found $(p=0.05)$;

- no statistically significant difference was confirmed for average arithmetical profile deviations $(p=0.05)$ of machined surfaces for the tested coatings $\left(\left(\mathrm{Ti}_{0.4}, \mathrm{Al}_{0.6}\right) \mathrm{N}\right.$, (Ti,Al)N).

\section{ACKNOWLEDGEMENTS}

This research work was supported by the FME BUT Brno, Czech Republic as the "Research of perspective production technologies", FSI-S-19-6014 and Ministry of Industry and Trade, project "Application of the New Surface Treatment Technologies in Metal Packaging Industry", FV40313.

\section{REFERENCES}

[Bobzin 2017] Bobzin, K. High-performance coatings for cutting tools. CIRP Journal of Manufacturing Science and Technology. 2017; 18:1-9.

[Derflinger 2006] Derf linger, V. H., Schutze, A. and Ante, M. Mechanical and structural properties of various alloyed TiAIN-based hard coatings. Surface $\&$ Coatings Technology, 2006, Vol. 200, pp. $4693-4700$.

[Ee 2003] Ee, K.C., Balaji, A.K. and Jawahir, I.S. Progressive Toolwear Mechanisms and their Effects on Chip Curl/Chipform in Machining with Grooved Tools. Wear, 2003, Vol. 255, pp. 1404-1413.

[Fofana 2003] Fofana, M.S., Ee, K.C. and Jawahir I.S., Machining Stability in Turning Operations when Cutting with a Progressively Worn Tool Insert. Wear, 2003, Vol. 255, pp. 1395-1403.

[Forejt 2006] Forejt, M., Piska, M. Theory of Machining, Forming and Cutting tools. Brno: CERM, 2006. ISBN 80-214-2374-9

[Humar 2008] Humar, A. Materials For Cutting Tools. Prague: MM publishing, 2008. ISBN 978-80-254-2250-2

[Jawahir 2000] Jawahir, I. S. and Balaji, A. K. Predictive Modeling and Optimization of Turning Operations with Complex Grooved Tools for Curled Chip Formation and Chip Breaking. Machining Science \& Technology,2000, Vol. 4, pp. 399-443.

[Klostermann 2005] Klostermann, H., Bfcher, B., Fietzke, F., Modes, T. and Zywitzki, O. Nanocomposite oxide and nitride hard coatings produced by pulse magnetron sputtering. Surface \& Coatings Technology, 2005, Vol. 200, pp. $760-764$.

[Parakkal 2001] Parakkal, G., Zhu, R., Kapoor, S. G. and DeVor, R. E. Modeling of turning process cutting forces for grooved tools. International Journal of Machine Tools \& Manufacture, 2002, Vol. 42, pp.179-19.

[Rech 2006] Rech, J. Influence of cutting tool coatings on the tribological phenomena at the tool-chip interface in orthogonal dry turning. Surface \& Coatings Technology, 2006, Vol. 200, pp. $5132-5139$.

[Shaw 2005] Shaw, M. C. Metal Cutting Principles. New York: Oxford University Press, 2005. ISBN 0-19-514206-3

[Vijayan 2018] Vijayan, D., Manoj Kumar, Y.G. A Preliminary Investigations on Second Generation Nano Composite Super Nitride Coatings on Astm A681 Tool Steels. 3rd International Conference on Materials and Manufacturing Engineering 2018, IOP Conf. Series: Materials Science and Engineering 390 (2018) 012054; Kanchipuram, Tamilnadu; India; 8.-9.3.2018; doi:10.1088/1757-899X/390/1/012054

[Wanigarathne 2005] Wanigarathne, P.C., Kardekar, A.D., Dillon, O. W., Poulachon, G. and Jawahir, I.S. Progressive Tool-wear in Machining with Coated Grooved Tools and Its Correlation with Cutting Temperature, Wear, 2005, Vol. 259, pp. 1215-1224.

\section{CONTACTS:}

Prof. Ing. Miroslav Piska, CSc.

Brno BUT, Faculty of Mechanical Engineering, Institute of Manufacturing Technology,

Technicka 2, 61669 Brno, Czech Republic

tel.: +420 54114 2555, e-mail: piska@fme.vutbr.cz 